\title{
NEW EVIDENCE OF BROWN GLAZE STONEWARE KILNS ALONG THE EAST ROAD FROM ANGKOR
}

\author{
Mitch Hendrickson \\ ACLS/Henry Luce Postdoctoral Fellow, Dept. Archaeology, University of Calgary, Calgary, AB T2N 1N4, Canada \\ Email: mjhendri72@yahoo.ca \\ Keywords: Cambodia, Angkor, stoneware, ceramics, kilns
}

\begin{abstract}
Brown-glazed ceramics are commonly found at Angkorian period sites yet our knowledge of production and distribution of these wares has been limited to kilns in Thailand and along the Angkorian roads west of the capital. Recent survey along the road connecting Beng Melea with Preah Khan of Kompong Svay has identified the first evidence of brown glazed ceramic kilns east of Angkor. Nearby Angkorian temples suggest that the kilns were in operation at least by the beginning of the $12^{\text {th }}$ century. This confirms that brown glazed ceramics were made locally and not imported from northeast Thailand or western Cambodia. The proximity to the Angkorian road also suggests that ceramics from these kilns were redistributed along this route to provide local communities and, potentially, the capital. The implication of these new discoveries is that the Angkorian transport system served as an important mechanism for industrial and commercial activity and not just connections between major temple centres.
\end{abstract}

\section{ANGKORIAN CERAMICS AND CAMBODIAN KILNS}

The production and re-distribution of glazed stoneware ceramics during the Angkorian period $\left(9^{\text {th }}-15^{\text {th }}\right.$ centuries) is poorly understood. Aymonier (1901:414) identified the first glazed ceramic kilns on the Phnom Kulen at the site of Anlong Thom, and by 1970 B-P. Groslier (1981:17) had only noted the presence of production sites near Sambor Prei Kuk and Preah Khan of Kompong Svay. Since 1995, interest in ceramics has dramatically increased, and combined with looting, development and demining activities several more kilns have now been identified around Angkor (see Nara National Cultural Properties Research Institute 2000; Ea 2006) and in Banteay Meanchey province (see Ea 2007). Of these kilns, however, only those found in Banteay Meanchey have produced the characteristic brown glazed ware commonly found across Angkor territory from the late $10^{\text {th }}$ century. These dominated ceramic assemblages up to the late $12^{\text {th }}$ century and may have continued into the $14^{\text {th }}$ century (Mourer 1986:165-170; Fine Arts Department
1989:141; Shimizu 2000:204). Brown glaze kilns were first identified and excavated in northeast Thailand at the sites of Ban Kruat and Ban Phluan (Brown 1981:43; Rooney 1984:17; see Fine Arts Department 1989). Proximity to the Angkorian road connecting to Phimai and corresponding lack of kilns in Cambodia led to the hypothesis that northeast Thailand was the production/distribution hub for brown glazed ceramics throughout the empire (Rooney 1984:35; Brown 1989:46; Cort 2000:125). While this hypothesis was compromised by the fact that kilns had not been actively sought in Cambodia at that time, B-P. Groslier denied that provincial ceramics were present in Angkor (Groslier 1981:16-17). Recent discovery of brown glaze kilns on the west road from Angkor by the Living Angkor Road Project (Ea 2007) has now shifted production into Cambodia but evidence for brown glaze kilns around the capital and further east until now had not been located.

\section{SURVEY ALONG THE EAST ROAD: TEAP CHEI}

Ground survey along the Angkorian road connecting the large temple enclosures of Beng Melea (est. early $12^{\text {th }}$ century) and Preah Khan of Kompong Svay (est. early $11^{\text {th }}$ century) was completed in March 2008 (Fig. 1). Recent research by the author (see Hendrickson 2007) has argued that these temples were important nodes in the distribution of economic products, specifically iron, to the capital and throughout the empire from at least the early $12^{\text {th }}$ century. The objective of the survey was to identify settlement features such as ponds and occupation mounds around the Jayavarman VII era (1181 to 1220 CE) dharmasalas, or resthouses. Spaced at 12 to $15 \mathrm{~km}$ intervals apart the dharmasalas represent an ideal location for identifying further evidence of economic activity along the roads. The site of Teap Chei is situated $14 \mathrm{~km}$ east-southeast of Beng Melea and is the first sandstone dharmasala on the route connecting to Preah Khan of Kompong Svay. As with all dharmasalas along the east road Teap Chei is built close to a Suryavarman II period (1113 to c.1150 CE) temple d'étape, known as Prasat Teap Chei (see Parmentier 1948:112-113). Records of the dharmasalas by Lunet de Lajonquière (1911:xxix) and a later summary of these temples by Finot (1925) made no mention of any settlement-related features in the immediate vicinity of the temples. 


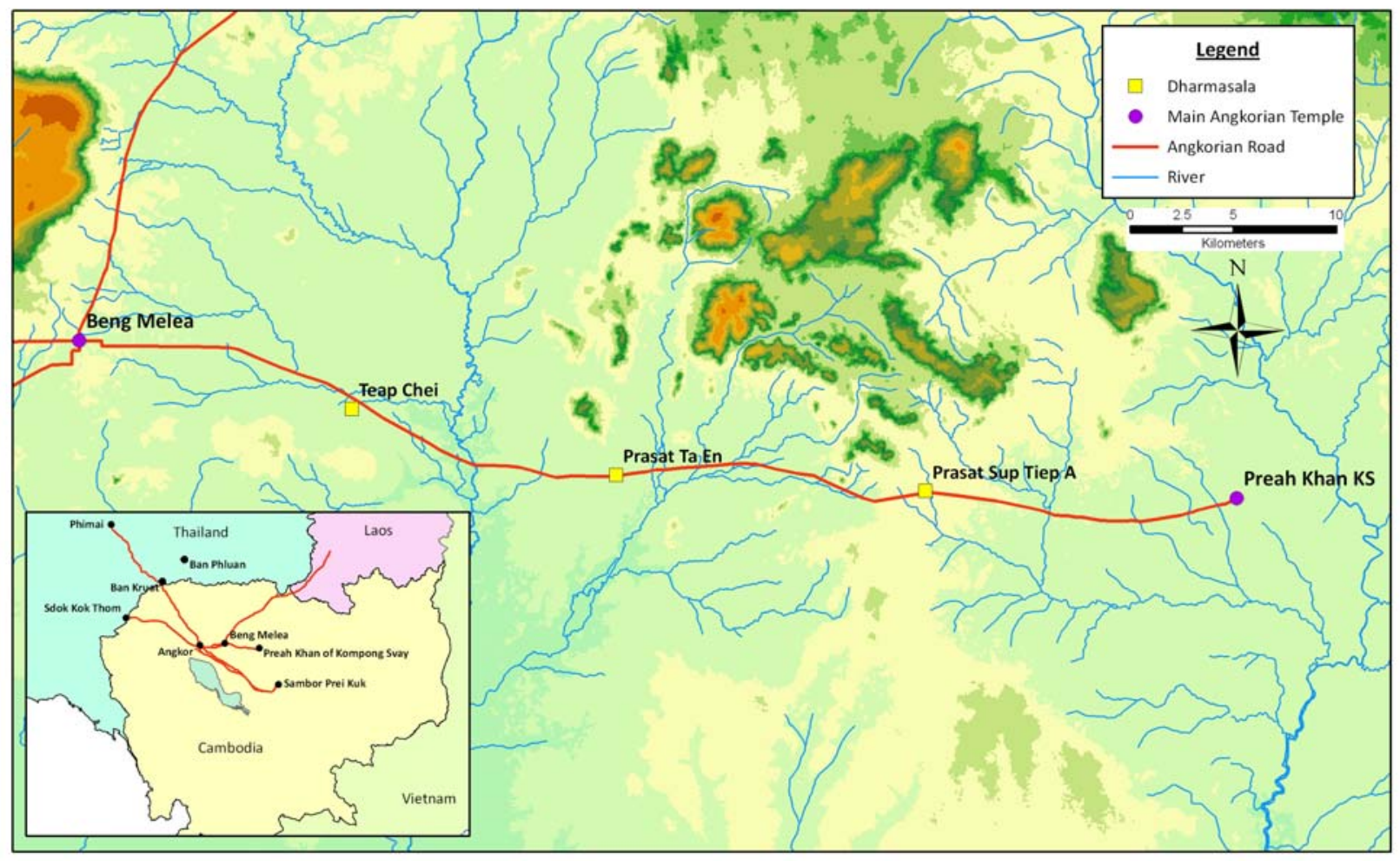

Figure 1. Map of resthouse sites located along the Angkorian road between Beng Melea and Preah Khan of Kompong Svay (GIS data from Mekong River Commission Interactive Atlas 2005; background DEM SRTM 90m DEM [http://srtm.csi.cgiar.org])

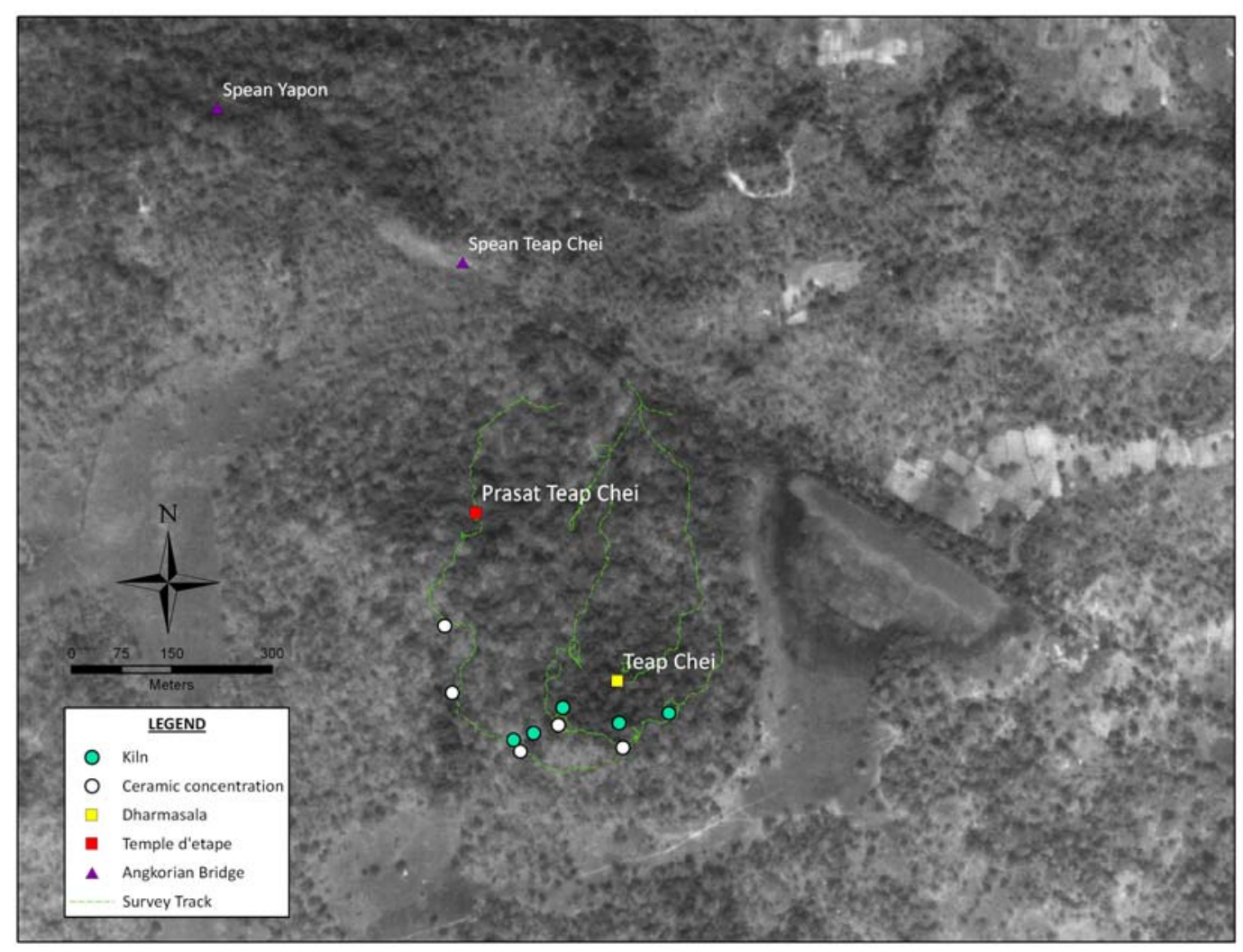

Figure 2. Ceramic sites found in the vicinity of Teap Chei (background - Finnmap 1992 black and white aerial photograph 08-32W1978) 


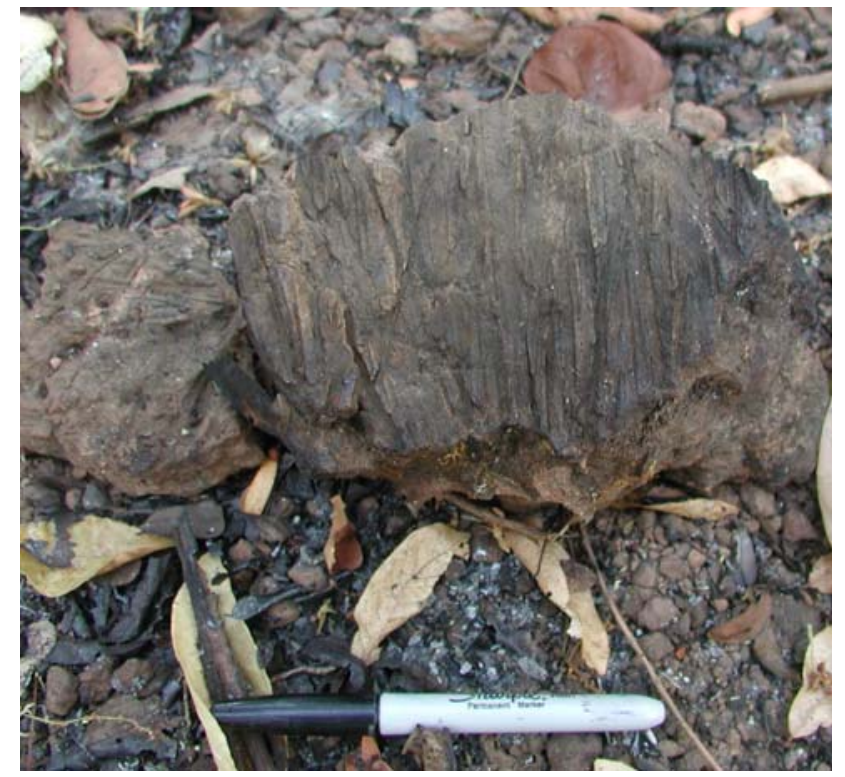

Figure 3. Bamboo mat impression in clay found on mound of Kiln 1

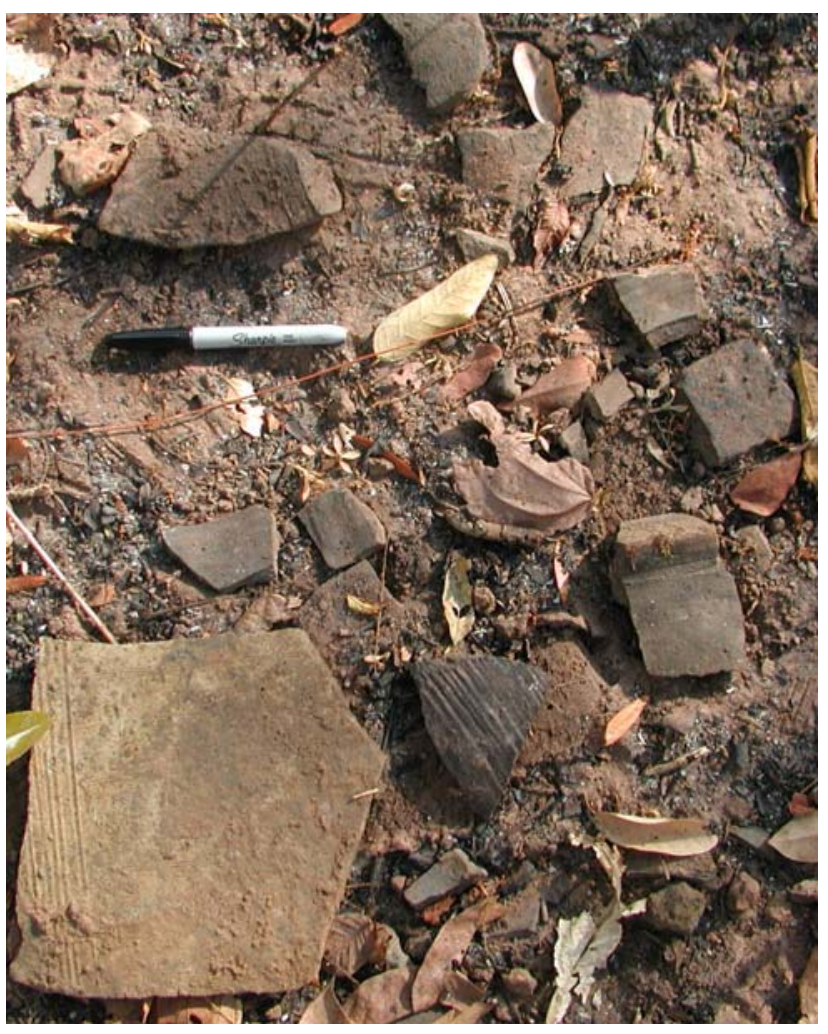

Figure 4. Brown glazed and unglazed ceramics found on mound of Kiln 1

Ground surveys recorded tracklogs and point locations with a Trimble Juno GPS unit over a two day period identified substantial surface scatters of ceramic materials in close proximity to the Teap Chei temples. In addition to these ceramic concentrations three kiln mounds were found (Kiln 1, 3 and 5) as well as two ablated structures (Kiln 2 and 4 ) in the immediate vicinity (Fig. 2). A local

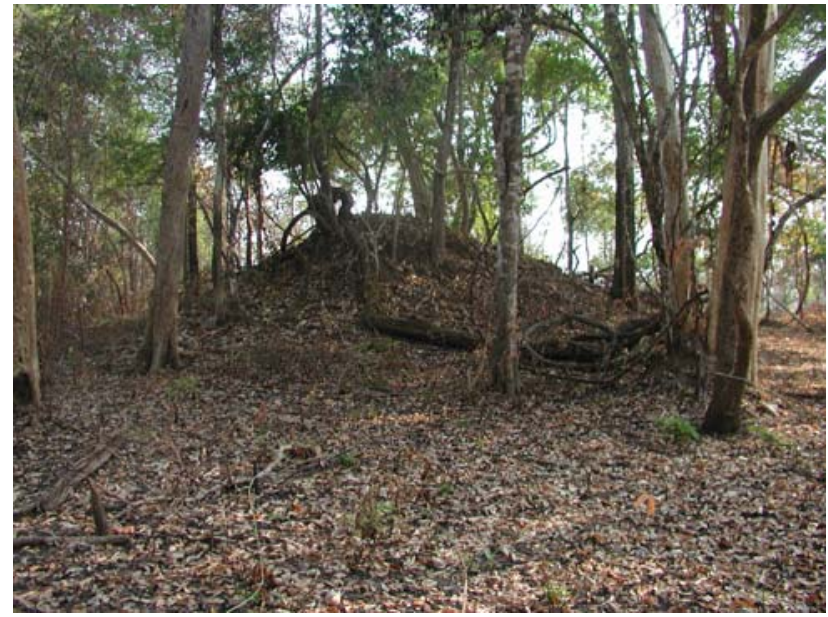

Figure 5. Mound of Kiln 1

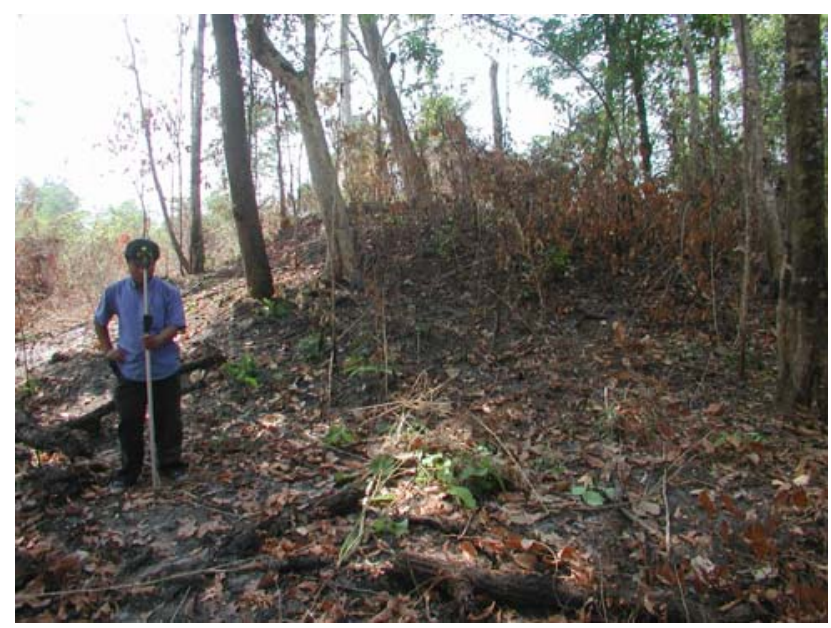

Figure 6. Mound of Kiln 3

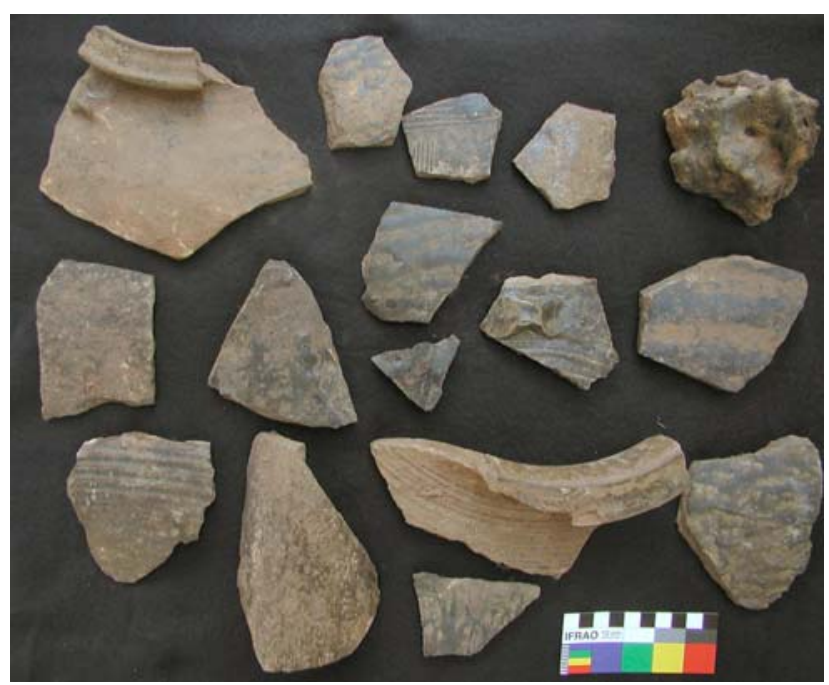

Figure 7. Brown glazed ceramics from Kiln 1 (curved roof tile, bottom row $2^{\text {nd }}$ from left)

informant indicated that another kiln was located to the southeast of Prasat Teap Chei but it was not possible to confirm this. The mounds were recognized as kilns from 


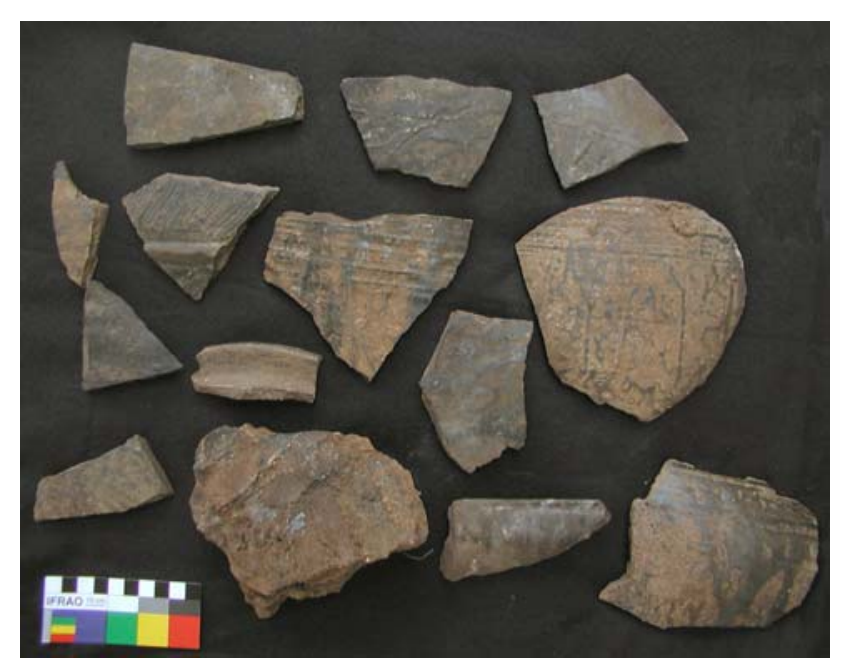

Figure 8. Brown glazed sherds from Kiln 3 (flat roof tile, upper left)

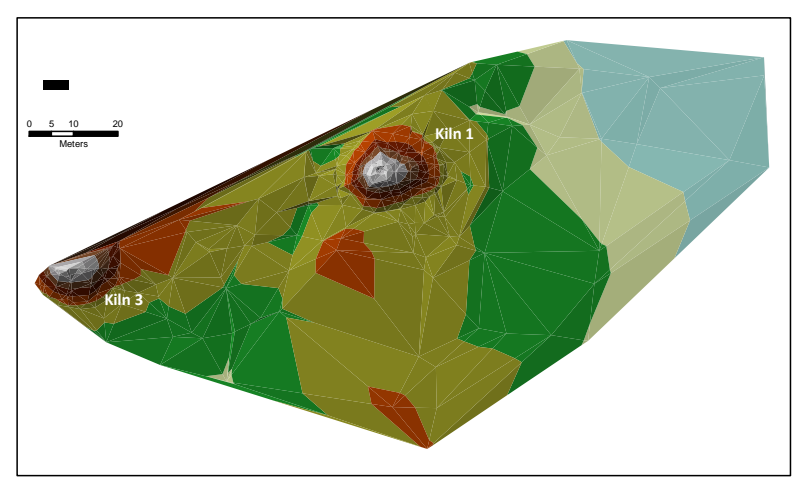

Figure 9. Survey map of Kiln 1 and Kiln 3

the dense concentration of broken pieces of fired clay, including pieces with impressed bamboo and finger-prints (Fig. 3), and the density quantity of large sherds from brown glazed and unglazed jars (Fig. 4).

Kiln 1 (Fig. 5) and 3 (Fig. 6) are the largest kilns in the Teap Chei group. Ceramics found on the mound of Kiln 1 included large jars and a single brown glazed curved roof tile (Fig. 7). A looting pit in the crown of Kiln 1 also revealed remnants of the internal chamber walls and a local villager indicated that large complete jars had been found there. The cleared area marked as Kiln 2 was notable for the appearance of biscuit ware (low-fired pottery) pieces. Kiln 3 is also predominated by large vessel forms and also had a single example of a flat roof tile (Fig. 8). Kiln 4 was identified by a local villager and appears to have been largely destroyed, with several dead trees lying on top of the small mound. Initial inspection of ceramics from Kiln 4 suggests that the wares were more green-brown than the true chocolate brown coloured vessels found at Kilns 1 and 3. More detailed comparison is required to determine whether this represents different glaze or merely sample selection. Kiln 5 , located close to Kiln 4, is a small mound approximately $1 \mathrm{~m}$ in height and 8-9 $\mathrm{m}$ in length. Again the surface of the mound and surrounding area was covered with kiln wasters and fragments of brown-glazed ceramics.

A total station survey of Kiln 1 and 3 (Fig. 9) showed that both mounds are east-west oriented with their crown on the western side. The kilns have similar dimensions of 19 to $19.5 \mathrm{~m}$ in length, 15 and $17 \mathrm{~m}$ wide and $3 \mathrm{~m}$ in height at their crown. Size, orientation and distribution of the Teap Chei kilns therefore correspond to the artificial mounds found at the Tani kilns, east of Phnom Bok (see Aoyagi et al. 2000; Nara National Cultural Properties Research Institute 2001).

\section{Chronology}

The first appearance of brown glazed ceramics is variously associated with the end of the $10^{\text {th }}$ century or the early $11^{\text {th }}$ century (see Brown 1989:51; Baty 2005:131). Throughout the $11^{\text {th }}$ century, brown glazed ceramics continued to replace the green glaze 'Kulen' wares and became the predominant type during from the $12^{\text {th }}$ century and continued until the $13^{\text {th }}$ century (see Mourer 1986:166-170). The ceramics from the kilns at Teap Chei include both brown glazed and unglazed vessels. Further comparison of glaze colour needs to be completed to assess which phase of the sequence these vessels correspond. Based on the local architectural evidence from Prasat Teap Chei, a Suryavarman II (1102-1150 CE) period temple, and Teap Chei, the Jayavarman VII dharmasala (1181-1218 CE), it appears that the kilns were likely in use at least by the first half of the $12^{\text {th }}$ century.

\section{Significance}

The discovery of the Teap Chei kilns has a twofold significance. First, it demonstrates that the ubiquitous $12^{\text {th }}$ to $13^{\text {th }}$ century brown glaze ceramics were produced to the east of Angkor. No longer can we attribute the production and distribution of brown glazed ceramics from the known kilns in Thailand. Second, the presence of numerous kilns near the road between Beng Melea and Preah Khan suggests that the goods were distributed within the immediate vicinity, and possibly to Angkor. This corroborates the location of the Ban Kruat kiln and recent findings of the Living Angkor Road Project (see Ea 2007) which has identified similar brown glaze kilns along the roads to Sdok Kok Thom and Phimai from the capital.

The question now becomes whether the kilns along the roads within Cambodia, and specifically those east of Angkor are contemporary with those in Thailand. Determining the age of these kilns is now vital for understanding the transmission of ceramic technology and ultimately determining factors for understanding why we find kilns in the landscape today. It is important to investigate whether the brown glaze industry first arose in Thailand, or whether it was transmitted to this region from Cambodia. A further line of inquiry that must be considered is why only green and not brown glaze producing kilns were established around the capital. Perhaps the requirements of ceramic production, specifically wood fuel, exceeded 
local resource - particularly given the capital would have required substantial wood resources for domestic fuels and construction - and therefore required outsourcing in provincial regions.

\section{CONCLUSION}

After decades of civil strife and the slow removal of the landmine threat in Cambodia, it is now possible to access the archaeological information in remote regions of Cambodia to shed light on the internal workings of the Angkorian empire. Discovery of kilns along the road between Beng Melea and Preah Khan of Kompong Svay provides first evidence that brown glaze ceramics were produced east of Angkor. Previous discussions of brown glazed wares being produced and transported exclusively from Ban Kruat and Ban Phluan can now be put aside. Given the proximity to two temples dating to the $12^{\text {th }}$ century, it is likely that the kilns were active at least by this time. Further archaeological work at Teap Chei and other sites along the Angkorian roads will shed more light on the nature of Angkorian ceramic production/distribution and help to define the chronological sequence of brown glaze ceramics. From a broader perspective the Teap Chei kilns represent the first evidence for economic activity along the East road. This new information corroborates the author's previous claims (see Hendrickson 2007) that the Angkorian transport system operated at multiple scales (local traffic, state-level demands) and served multiple functions (military, pilgrimage, trade) between the $11^{\text {th }}$ to $13^{\text {th }}$ centuries.

\section{ACKNOWLEDGEMENTS}

This research was aided by a Fellowship for East Asian Archaeology and Early History from the American Council of Learned Societies, with funding from the Henry Luce Foundation. I want to individually thank Lanh Udomrangsey, the Greater Angkor Project, An Sopheap, APSARA Authority, Christophe Pottier and the École Française d'Extrême Orient, Dougald O'Reilly and HeritageWatch, Ngaire Richards, Son Chanthoeun, Chan Sovichetra and Damian Evans who assisted in various ways to enable the field work to be completed. I would also like to thank Dan Penny, Liz Holt and two reviewers who provided important comments. Any inconsistencies or errors are solely my own.

\section{REFERENCES}

Aoyagi, Y., T. Sasaki, K. Tanaka, T. Nogami, M. Marui, and T. Sumida. 2000. Excavation of a Khmer ceramic kiln site: report of the investigation of Kiln B1, Tani Kiln Complex. UDAYA 1:217-234.

Baty, P. 2005. Extension de l'Aéroport de Siem Reap. Rapport de diagnostic archéologique. Trapeang Thlok - Prasat Trapeang Ropou. Rapport de fouille archéologique. Trapeang Thlok - Sanctuaire et Habitat. Base INRAP de Poitiers.
Brown, R. 1981. Khmer ceramics of the Korat Plateau. In D. Stock (ed.), Khmer Ceramics 9th-14th Century, pp. 41-50. Singapore: Southeast Asian Ceramic Society.

----- 1989. The Ceramics of South-East Asia. Their Dating and Identification. Singapore: Oxford University Press.

Cort, L.A. 2000. Khmer stoneware ceramics. The Hague Gifts. In L.A. Cort, M. Farhad, and A.C. Gunter (eds), Asian Traditions in Clay, pp. 91-149. Washington DC: Freer Gallery of Art and Arthur M. Sackler Gallery, Smithsonian Institution.

Ea, D. 2006. An introduction to new data on Khmer kiln sites. Paper presented at the 18th Congress of the Indo-Pacific Prehistory Association, Manila, the Philippines, March 20-26.

----- 2007. New data on the distribution of Khmer ceramics kilns. Paper presented at Ancient Khmer and Southeast Asian Ceramics: New Archaeological Findings, Production and the Revival of Techniques. Centre for Khmer Studies, Siem Reap, Cambodia, December 13-15.

Fine Arts Department. 1989. Ancient Kiln Sites in Buriram province. Bangkok: Fine Arts Department.

Finot, L. 1925. Dharmaçalas du Cambodge. Bulletin de l'École Française d'Extrême Orient 25:417-422.

Groslier, B-P. 1981. Introduction to the ceramic wares of Angkor. In D. Stock (ed.), Khmer Ceramics 9th-14th Century, pp. 9-40. Singapore: Southeast Asian Ceramic Society.

Hendrickson, M. 2007. Arteries of Empire: an Operational Study of Transport and Communication in Angkorian Southeast Asia (9th to 15th centuries CE). Unpublished PhD Thesis. University of Sydney: Sydney.

Lunet de Lajonquière, É. 1911. Inventaire Descriptif des Monuments du Cambodge. Vol. III. Publications de l'EFEO (9). Paris: Ernest Leroux.

Mourer, R. 1986. La Poterie au Cambodge. Histoire et Développement. Essai d'Éthno-Technologie. 2 Volumes. PhD, École des Hautes Études en Sciences Sociales. Paris.

Nara National Cultural Properties Research Institute, and APSARA Authority. 2000. Recent research on kiln sites in the Angkor area. UDAYA 1:217-234.

----- 2001. Investigation of the Tani Kiln Site: geophyiscal prospections, excavations and site presentation proposal. UDAYA 2:133-140.

Parmentier, H. 1948. L'Art Architectural Hindou dans l'Inde et en Extême-Orient. Paris: van Oest.

Rooney, D. 1984. Khmer Ceramics. Singapore: Oxford University Press.

Shimizu, Naho. 2000. Preliminary report on ceramics recovered from the Northern 'Library' of the Bayon Complex, Angkor Thom. UDAYA 1:201-216. 